\section{Raquel Esgueva ${ }^{1}$, Francesca Demichelis ${ }^{1,2}$ and Mark A Rubin ${ }^{1}$}

${ }^{1}$ Department of Pathology and Laboratory Medicine, Weill Cornell Medical College, New York, NY, USA and ${ }^{2}$ Institute for Computational Biomedicine, Weill Cornell Medical College, New York, NY, USA E-mail: rubinma@med.cornell.edu

\section{References}

1 Lotan TL, Toubaji A, Albadine R, et al. TMPRSS2-ERG gene fusions are infrequent in prostatic ductal adenocarcinomas. Mod Pathol 2009;22:359-365.

2 Perner S, Demichelis F, Beroukhim R, et al. TMPRSS2:ERG fusion-associated deletions provide insight into the heterogeneity of prostate cancer. Cancer Res 2006;66:8337-8341.

3 Nam RK, Sugar L, Wang Z, et al. Expression of TMPRSS2 ERG gene fusion in prostate cancer cells is an important prognostic factor for cancer progression. Cancer Biol Ther 2007;6:40-45.

4 Mehra R, Tomlins SA, Shen R, et al. Comprehensive assessment of TMPRSS2 and ETS family gene aberrations in clinically localized prostate cancer. Mod Pathol 2007;20:538-544.

5 Attard G, Clark J, Ambroisine L, et al. Duplication of the fusion of TMPRSS2 to ERG sequences identifies fatal human prostate cancer. Oncogene 2008;27:253-263.
6 Demichelis F, Fall K, Perner S, et al. TMPRSS2:ERG gene fusion associated with lethal prostate cancer in a watchful waiting cohort. Oncogene 2007;26: 4596-4599.

7 Tomlins SA, Rhodes DR, Perner S, et al. Recurrent fusion of TMPRSS2 and ETS transcription factor genes in prostate cancer. Science 2005;310:644-648.

8 Ward JF, Blute ML, Slezak J, et al. The long-term clinical impact of biochemical recurrence of prostate cancer 5 or more years after radical prostatectomy. J Urol 2003;170:1872-1876.

9 Carver BS, Bianco Jr FJ, Scardino PT, et al. Long-term outcome following radical prostatectomy in men with clinical stage T3 prostate cancer. J Urol 2006;176:564-568.

10 Porter CR, Kodama K, Gibbons RP, et al. 25-year prostate cancer control and survival outcomes: a 40year radical prostatectomy single institution series. J Urol 2006;176:569-574.

11 Stamey TA, Caldwell M, McNeal JE, et al. The prostate specific antigen era in the United States is over for prostate cancer: what happened in the last 20 years? J Urol 2004;172(4 Pt 1):1297-1301.

12 Tomlins SA, Laxman B, Dhanasekaran SM, et al. Distinct classes of chromosomal rearrangements create oncogenic ETS gene fusions in prostate cancer. Nature 2007;448:595-599.

13 Helgeson BE, Tomlins SA, Shah N, et al. Characterization of TMPRSS2:ETV5 and SLC45A3:ETV5 gene fusions in prostate cancer. Cancer Res 2008;68:73-80.

14 Rickman D, Pflueger D, Moss B, et al. SLC45A3-ELK4 is a novel and frequent ETS fusion transcript in prostate cancer. Cancer Res 2009;69:2734-2738.

\title{
Response to Esgueva et al
}

Modern Pathology (2009) 22, 1399-1400; doi:10.1038/modpathol.2009.102

In Reply: It is with great interest and appreciation that we read the comments by Esgueva et $a l^{1}$ in relation to our paper titled 'TMPRSS2-ERG gene fusions are infrequent in prostatic ductal adenocarcinomas' published in the March 2009 issue of the journal of Modern Pathology. ${ }^{2}$

We agree with the authors' statement that studies assessing the relationship between ERG fusion and clinical outcome have so far yielded conflicting results. $^{3-9}$ The main objective of our study was to evaluate the previously not-assessed incidence of TMPRSS2-ERG fusion in a well-characterized cohort of prostatic ductal carcinoma. Considering the welldocumented aggressive behavior of prostatic ductal carcinoma, our finding of a relatively low incidence of TMPRSS2-ERG fusion in such tumors could be seen as indirect evidence arguing for its lack of association with aggressive outcome.

A comprehensive review of the previous literature on the relationship of fusion with outcome was neither attempted nor implied in our discussion, given the above well-defined focus of our study. In this regard, the omission of the study by Attard et $a l^{4}$ was definitely unintentional. By citing examples from two groups of studies showing conflicting evidence on the association of TMPRSS2-ERG fusion with aggressive outcome, we simply attempted to illustrate the controversy rather than to provide a comprehensive categorization of the end points and cohort details of all previous studies.

The authors' speculation regarding the possibility of symptomatic presentation as a potential common denominator between our cohort and the expectant management cohort of patients diagnosed on TURP in the report by Demichelis et $a l^{3}$ is intriguing but unlikely to be relevant in our cohort. As we detail in the 'Materials and methods' section of our paper, our cohort was diagnosed through PSA screening and/or through digital rectal examination. Furthermore, despite earlier reports, it is now well recognized that only a minority of prostatic ductal adenocarcinomas are completely limited to the central location, and similar to acinar prostatic carcinomas they are more likely to be discovered during PSA screening, as certainly was the case in our cohort. ${ }^{10}$

Finally, the break-apart FISH strategy that we adopted in our study is identical to the one used by two of the authors on the above commentary, 
in several of their previous TMPRSS2-ERG fusion reports. $^{11,12}$ Therefore, it is somewhat surprising that the authors have chosen to raise doubts about the validity of this methodology as they have previously documented its utility using quantitative PCR analysis. ${ }^{12}$

We thank the letter authors for their comments and for the opportunity to clarify some of the issues they raised.

George J Netto, Tamara Lotan, Roula Albadine, Mathieu Latour, Angelo M Demarzo and Alan Meeker

Department of Pathology, Urology and Oncology, Johns Hopkins University, Baltimore, MD, USA E-mail: gnetto1@jhmi.edu

\section{References}

1 Esgueva R, Demichelis F, Rubin MA. TMPRSS2-ERG gene fusions are infrequent in prostatic ductal adenocarcinomas. Mod Pathol 2009;22:1398-1399 (this issue).

2 Lotan TL, Toubaji A, Albadine R, et al. TMPRSS2-ERG gene fusions are infrequent in prostatic ductal adenocarcinomas. Mod Pathol 2009;22:359-365.

3 Demichelis F, Fall K, Perner S, et al. TMPRSS2:ERG gene fusion associated with lethal prostate cancer in a watchful waiting cohort. Oncogene 2007;26: 4596-4599.

4 Attard G, Clark J, Ambroisine L, et al., Transatlantic Prostate Group. Duplication of the fusion of TMPRSS2 to ERG sequences identifies fatal human prostate cancer. Oncogene 2008;27:253-263.

5 Saramaki OR, Harjula AE, Martikainen PM, et al. TMPRSS2:ERG fusion identifies a subgroup of prostate cancers with a favorable prognosis. Clin Cancer Res 2008;14:3395-3400.

6 Gopalan A, Leversha MA, Satagopan JM, et al. TMPRSS2-ERG gene fusion is not associated with outcome in patients treated by prostatectomy. Cancer Res 2009;69:1400-1406.

7 Toubaji A, Albadine R, Meeker AK, et al. Chromosome 21 copy number but not TMPRSS2-ERG fusion predicts outcome in prostatic adenocacrcinoma: a large case-control radical prostatectomy cohort analysis. Mod Pathol 2009;22(Suppl 1):189A pp.

8 Nam RK, Sugar L, Wang Z, et al. Expression of TMPRSS2:ERG gene fusion in prostate cancer cells is an important prognostic factor for cancer progression. Cancer Biol Ther 2007;6:40-45.

9 Nam RK, Sugar L, Yang W, et al. Expression of the TMPRSS2:ERG fusion gene predicts cancer recurrence after surgery for localised prostate cancer. Br J Cancer 2007;97:1690-1695.

10 Brinker DA, Ross JS, Tran TA, et al. Can ploidy of prostate carcinoma diagnosed on needle biopsy predict radical prostatectomy stage and grade? J Urol 1999;162:2036-2039.

11 Tomlins SA, Rhodes DR, Perner S, et al. Recurrent fusion of TMPRSS2 and ETS transcription factor genes in prostate cancer. Science 2005;310:644-648.

12 Perner S, Mosquera JM, Demichelis F, et al. TMPRSS2-ERG fusion prostate cancer: an early molecular event associated with invasion. Am J Surg Pathol 2007;31:882-888. 